\title{
ASPEK HUKUM TENTANG BLACK CAMPAIGN PADA PLATFORM MEDIA SOSIAL INSTAGRAM
}

\author{
Candra Ulfatun Nisa, Hari Sutra Disemadi, Kholis Roisah \\ Fakultas Hukum Universitas Diponegoro, Semarang-Indonesia \\ Email: candraulfatun@gmail.com
}

\begin{abstract}
ABSTRAK
Metode kampanye politik mengalami perkembangan hingga pada pemanfaatan media sosial sebagai bentuk adanya kemajuan teknologi dan informasi, salah satunya media sosial Instagram. Pemanfaatan media sosial Instagram dalam kampanye politik sering disalahgunakan untuk penyebaran black campaign. Efek yang ditimbulkan black campaign tidak sekedar tercorengnya nama baik peserta pemilu saja, tetapi juga berefek bagi masyarakat dalam hal hak mendapatkan suatu informasi pemilu secara akurat dan objektif. Penelitian ini bertujuan untuk mengetahui tatanan hukum sekaligus akibat hukum terhadap black campaign melalui media sosial Instagram. Metode pendekatan yang digunakan adalah pendekatan doktrinal, dengan spesifikasi penelitian deskriptif. Penelitian ini menggunakan teknik pengumpulan data yang didasarkan pada data sekunder. Hasil penelitian menunjukkan tatanan hukum mengenai pelaksanaan kampanye melalui media sosial diatur secara rinci dalam Peraturan Komisi Pemilihan Umum Nomor 28 Tahun 2018 tentang Perubahan atas Peraturan Komisi Pemilihan Umum Nomor 23 Tahun 2018 tentang Kampanye Pemilihan Umum. Akibat hukum yang ditimbulkan dapat dijerat dengan Undang-Undang Nomor 7 Tahun 2017 Tentang Pemilihan Umum dan Undang-Undang Nomor 19 Tahun 2016 Tentang Perubahan Atas Undang-Undang Nomor 11 Tahun 2008 Tentang Informasi Dan Transaksi Elektronik, yang memunculkan adanya dualisme undang-undang. Bahkan, penafsiran mengenai subjek tindak pidana pemilu khususnya peserta masih belum selaras, sehingga menimbulkan ketidakpastian dan ketidakadilan bagi masyarakat.
\end{abstract}

\section{Kata Kunci: Pemilu, Kampanye Hitam, Media Sosial}

\section{ABSTRACT}

Political campaign methods that enhance development on social media as a form of existence of technological and information advancements, for example social media Instagram. The use of social media Instagram in political campaigns is often used for black campaigns. The effects of the black campaign are not just tarnishing the good name of election participants, but also having an effect on society in terms of the right to obtain accurate and objective election information. This study aims to determine the legal order as well as to fight the black campaign through social media Instagram. The method used is a doctrinal approach, with descriptive research specifications. This study uses data collection techniques based on secondary data. The results showed that the legal order regarding the implementation of campaigns through social media is regulated in detail in the Election Commission Regulation Number 28 of 2018 on Amendments to the Election Commission Regulation Number 23 of 2018 on Election Campaigns.The resulting legal consequences can be charged with Law Number 7 of 2017 on Elections and Law Number 19 of 2016 on Amendments to Law Number 11 of 2008 on Information and Electronic Transactions, which gave rise to dualism of the law. In fact, the interpretation of the subject of electoral crime, especially participants is still not aligned, causing uncertainty and injustice for the community.

Keywords: Election, Black Campaign, Social Media 


\section{A. PENDAHULUAN}

Negara Kesatuan Republik Indonesia disebut-sebut sebagai negara yang sistem pemerintahannya mempunyai sifat demokrasi, yang umumnya diberi istilah sebagai negara demokrasi. Negara demokrasi merupakan suatu negara yang bercirikan sebagai penganut sistem pemerintahan yang mempunyai tujuan untuk terciptanya kedaulatan rakyat yang menandakan bahwa kekuasaan tertinggi dan kedaulatan dikuasai sepenuhnya oleh rakyat untuk kemudian selanjutnya pemerintah menjalankan hak dan wewenangnya atas nama rakyat. Maka tidak heran apabila seluruh rakyat mempunyai kedudukan hak yang setara untuk berkesempatan memberikan kontribusi secara aktif atau turut berproses dalam pengambilan keputusan yang pada akhirnya, keputusan tersebut akan berpengaruh terhadap nasib hidup orang banyak. ${ }^{1}$

Bentuk pemerintahan yang sifatnya demokrasi, dapat diwujudkan salah satunya dengan adanya kehidupan berpolitik yakni partai politik. Keberadaan partai politik selanjutnya memunculkan hal yang telah menjadi sebuah ketentuan umum berupa kegiatan untuk memilih presiden beserta wakil presidennya, kepala daerah tingkat kabupaten/kota maupun wakil-wakil rakyat. $^{2}$ Hal inilah yang dikenal dengan istilah pemilihan umum (pemilu) dalam sistem demokrasi, bahkan kebanyakan orang memberikan sebutan sebagai pesta demokrasi.

Pemilu merupakan suatu kegiatan yang diadakan sebagai salah satu perwujudan pemenuhan hak asasi manusia khususnya masyarakat Indonesia di bidang politik. Pemilu dipandang pula sebagai

\footnotetext{
${ }^{1}$ Nanik Prasetyoningsih, Dampak Pemilihan Umum Serentak Bagi Pembangunan Demokrasi Indonesia, Jurnal Media Hukum, Vol. 21, Nomor 2, Desember 2014, 251.

2 Miftah Toha, Birokrasi Politik Dan Pemilihan Umum Di Indonesia (Jakarta: Kencana, 2014), 113.
}

simbol sekaligus patokan dari demokrasi. ${ }^{3}$ Sebagai negara demokrasi, Indonesia dalam perkembangannya telah menerapkan sistem pemilu sejak tahun $1955 .^{4}$ Diadakannya pemilu tidak lain adalah untuk menciptakan kedaulatan rakyat, karena pada dasarnya seluruh rakyat tidak dapat memerintah sekaligus secara langsung dan bersamaan. Oleh karena itu, dibutuhkannya sebuah cara untuk memilih wakil dari rakyat agar dapat memerintah baik dalam suatu daerah maupun suatu negara, yakni memilih anggota Dewan Perwakilan Rakyat (DPR), anggota Dewan Perwakilan Daerah (DPD), presiden dan wakil presiden, dan untuk memilih anggota Dewan Perwakilan Rakyat Daerah (DPRD) untuk jangka waktu tertentu yang telah ditetapkan yakni selama 5 (lima) tahun dalam setiap 1 (satu) periode. Pemilu pun tidak dilaksanakan dengan sembarangan, tetapi tetap harus mengacu pada asas langsung, umum, bebas, rahasia, jujur dan adil, yang umumnya disingkat daan dikenal dengan istilah asas "luber jurdil". Hal ini diatur dalam Pasal 1 angka 1 Undang-Undang Nomor 7 Tahun 2017 Tentang Pemilihan Umum (UU 7/2017).

Kegiatan pemilu tidak dapat dipisahkan dengan suatu kegiatan yang umunya dikenal dengan istilah kampanye. Keduanya, baik itu pemilu maupun kampanye dapat diibaratkan bagai dua sisi mata uang logam yang tak terpisahkan antara satu dengan yang lainnya. Pasal 1 angka 35 UU 7/2017 memberikan definisi yang menyatakan bahwa kampanye pemilu adalah suatu kegiatan yang dilakukan oleh peserta pemilu atau pihak lain yang ditunjuk oleh peserta pemilu yakni partai politik yang berisi sekelompok orang yang terorganisir maupun oleh peserta pemilu perseorangan, yang isi materinya adalah

3 Nanik Prasetyoningsih, Dampak Pemilihan Umum Serentak Bagi Pembangunan Demokrasi Indonesia, 242.

4 Jerico Mathias Marpaung \& Tirta Mulya Wira Pradana, Efektifitas Peradilan Khusus Pemilu Menuju Pilpres 2019, Seminar Nasional Hukum Universitas Negeri Semarang, Vol. 4, Nomor 2, September 2018, 327 https://doi.org/10.15294/snh.v4i02.25599 
tidak lain untuk meyakinkan pemilih dengan menyampaikan sekaligus menawarkan visi, misi, program yang akan dijalankan dan diusahakan dan/atau sekaligus memperlihatkan citra diri peserta pemilu sebagai bentuk promosi.

Kampanye dikenal pula merupakan salah satu bagian dalam komunikasi politik. Komunikasi politik dalam hal ini merupakan sarana dan wahana yang dipersiapkan sebagai perantara untuk menyampaikan pesan-pesan politik. Komunikasi politik yang dimaksud dilakukan sebagai upaya untuk memberikan pengaruh bagi masyarakat secara terorganisir dan terus menerus dalam waktu yang telah ditetapkan. ${ }^{5}$ Proses pengupayaannya bertujuan sebagai bentuk partisipasi dalam mengedukasi masyarakat yang berkaitan dengan politik dan dalam pelaksanaanya tetap harus penuh tanggung jawab. Kampanye dapat dilakukan dengan berbagai cara yang telah diatur sedemikian rupa oleh peserta pemilu beserta tim sukses masing-masing. Hal tersebut dilakukan demi bertambahnya perolehan suara sebagai bentuk pencapaian dukungan massa pemilih untuk memenangkan pemilu. ${ }^{6}$ Selain untuk melakukan pencapaian dukungan dalam suatu proses pengambilan keputusan di dalam suatu kelompok, kampanye juga bisa dilakukan guna untuk mempengaruhi, menghambat, atau bahkan membelokkan suatu tujuan pencapaian yang dicitacitakan.

Faktanya, presiden dan wakil presiden, anggota DPR, anggota DPD dan anggota DPRD yang akan dipilih atau yang umumnya disebut dengan peserta pemilu, ada kemungkinan mempunyai kualitas yang seimbang yakni sama kebagusannya atau bahkan sama dalam hal keburukannya, baik

\footnotetext{
5 Antar Venus, Manajemen Kampanye; Panduan Teoritis Dan Praktis Dalam Mengefektifkan Kampanye Komunikasi (Bandung: Simbiosa Rekatama Media, 2004), 20.

6 Sherly Nelsa Fitri, Pro Kontra Gerakan Tagar \#2019gantipresiden Sebagai Sarana Kampanye Dalam Pemilu, Seminar Nasional Hukum Universitas Negeri Semarang, Vol. 4, Nomor 2, September 2018, 286.
}

dalam hal persepsi rakyat mengenai citra dirinya maupun dalam hal visi, misi dan rencana program kerja kedepannya. Untuk memperoleh dukungan suara sekaligus memenangkan pemilu, setiap peserta pemilu mempunyai strategi atau perencanaan yang berbeda-beda dalam melakukan kampanye. ${ }^{7}$ Pada kondisi seperti inilah strategi kampanye masing-masing peserta pemilu dapat difungsikan secara penuh yakni dengan membuat sekaligus mempromosikan citra diri yang dapat memberikan persepsi baik kepada masyarakat mengenai mana yang nantinya dinilai lebih unggul di mata masyarakat sebagai pemilih. Strategi kampanye dapat di artikan sebagai perencanaan secara menyeluruh oleh peserta pemilu baik secara perseorangan maupun oleh sekelompok orang atau organisasi politik yang sifatnya sebagai suatu hal yang sudah dapat dipastikan mengenai tindakan-tindakan apa saja yang kiranya akan dijalankan pada saat itu dalam jangka waktu tertentu, yang tujuannya tidak lain adalah untuk memperoleh dukungan politik dari masyarakat demi mencapai tujuan politik di masa yang akan datang. ${ }^{8}$ Kenyataannya, strategi kampanye sering kali dilakukan dengan menghalalkan berbagai cara sehingga dalam prosesnya, kampanye seolah-olah dianggap merupakan sebuah wahana untuk saling menjatuhkan antar peserta pemilu satu sama lain dan sekaligus berupaya keras membentuk citra diri sebagai bentuk promosi diri secara baik dan positif untuk meyakinkan pemilih.

Kondisi tersebut pada akhirnya memunculkan perdebatan. Perdebatan yang muncul tersebut sudah menjadi hal yang lumrah terjadi selama masa proses

7 Dini Hidayanti Herpamudji, Strategi Kampanye Politik Prabowo-Hatta Dan Perang Pencitraan Di Media Massa Dalam Pemilu Presiden 2014, Politika: Jurnal Ilmu Politik, Vol. 6, Nomor 1, Desember 2015 , 17 https://Doi.Org/10.14710/Politika.6.1.2015.13-24 Anwar Arifin, Komunikasi Politik: Filsafat-Paradigma-Teori-Tujuan-Aplikasi-Strategi dan Komunikasi Politik Indonesia ( Jakarta: Graha Ilmu, 2011) 145. 
kampanye, bahkan kadang kala perdebatan telah dimulai jauh sebelum masa kampanye berlangsung. Perdebatan dilakukan oleh hampir seluruh lapisan masyarakat, baik itu oleh para peserta pemilu sendiri, para anggota/simpatisan partai politik, hingga masyarakat biasa dengan latar belakang yang berbeda yang ironisnya belum tentu masyarakat tersebut akan berpartisipasi untuk ikut memilih pada saat hari pemungutan suara. ${ }^{9}$

Perdebatan yang terjadi hampir selalu diiringi dengan munculnya fenomena kampanye hitam atau yang biasa dikenal dengan istilah black campaign. Black campaign dilakukan dengan tujuan menjelek-jelekkan agar menjadi buruk di mata masyarakat, merugikan, menjatuhkan atau menyerang lawan politik, dilakukan dengan cara yang jahat di luar dari etika politik yakni tidak sesuai dengan fakta yang ada, diperoleh dari sumber yang tidak jelas dan menjurus pada fitnah dan hujatan. Black campaign seolah dianggap sebagai hal yang wajar dilakukan untuk meyakinkan pemilih. Bentuk kampanye seperti ini sudah pasti merugikan bagi para peserta pemilu dalam hal martabat, nama baik atau kehormatan yang harus dijaga selama masa kampanye dan juga masyarakat sendiri sebagai subjek penerima informasi.

Perkembangannya, kampanye yang dilakukan mengalami beberapa perubahan dalam hal sarana yang digunakan, sehingga dalam penyampaian visi, misi dan program kerja beserta segala sesuatu yang berkaitan dengan peserta pemilu dilakukan dengan cara yang sedikit berbeda. Hal ini berlaku pula pada black campaign. Dahulu black campaign dilakukan melalui pembagian atau penyebaran informasi melalui media cetak seperti pamflet, fotokopian artikel, spanduk dan lain-lain, yang di dalamnya berisikan mengenai informasi-informasi negatif pihak lawan kepada masyarakat luas. Penyebaran itu dilakukan oleh tim

9 Anwar Arifin, Komunikasi Politik: Filsafat-Paradigma-Teori-Tujuan-Aplikasi-Strategi dan Komunikasi Politik Indonesia, 146. sukses maupun simpatisan dari peserta pemilu yang terkait. ${ }^{10}$ Sekarang black campaign dilakukan dengan menggunakan media yang lebih canggih sebagai bentuk adanya kemajuan teknologi dan informasi. Perkembangan zaman telah menuntut peserta pemilu untuk bekerja lebih kreatif dalam menawarkan visi dan misinya kepada masyarakat, sehingga dalam hal ini media sosial mulai digunakan dalam bidang politik khususnya kampanye.

Penggunaan media sosial dalam bidang politik tentu saja beralasan, karena media sosial dianggap memberikan kemudahan dan sangat efektif untuk penyebaran informasi disamping pula sebagai sumber informasi, sehingga informasi yang ada menjadi cepat tersebar luas secara bebas dan dengan mudah mendapatkan tanggapan secara cepat dan langsung. Media sosial dapat diakses dengan mudah oleh siapapun, kapanpun dan dimanapun, sehingga kampanye melalui media sosial tidak mengeluarkan banyak biaya dan tentunya diminati semua kalangan. Selain itu, media sosial bisa menjadi tempat berdialog tentang perbedaan pendapat yang sangat berhubungan dengan dukungan atau penolakan atas ide tertentu. Oleh karena itu, kehadiran media sosial memberi pengaruh yakni politik masyarakat melalui internet menjadi meningkat lebih pesat. ${ }^{11}$

Media sosial yang paling sering digunakan dalam melakukan kampanye salah satunya adalah Instagram. Pemanfaatan Instagram dalam berkampanye nyatanya seringkali disalahgunakan oleh banyak oknum yang tidak bertanggung jawab yang dengan mudahnya menyisipkan black campaign dan sekaligus membuat situasi semakin memanas antara peserta pemilu satu dengan

${ }^{10}$ Alfred B. David Dodu, Penerapan Regulasi Politik Kampanye Hitam: Studi Kasus Pada Pilkada Kabupaten Banggai Tahun 2015, Jurnal Wacana Politik, Vol. 2, Nomor 1, Maret 2017, 57.

11 Sherly Nelsa Fitri, Pro Kontra Gerakan Tagar \#2019gantipresiden Sebagai Sarana Kampanye Dalam Pemilu, 284. 
lainnya. Media sosial Instagram memiliki potensi yang sangat besar dalam menyebarkan isu yang tidak benar sekaligus pula berpengaruh signifikan dalam mempengaruhi masyarakat dalam pengambilan keputusan. Tujuan penyebaran isu yang tidak benar tersebut tidak lain adalah sebagai bagian dari rencana untuk menjatuhkan lawan politik yang nantinya akan mempengaruhi masyarakat untuk mempercayai keberadaan isu tersebut. Meskipun black campain tidak selalu menjadi jaminan sebagai strategi yang efektif untuk mendongkrak perolehan suara, namun nyatanya praktek black campaign sudah dipastikan sebagai bentuk keonaran yang dapat meresahkan dan membuat masyarakat merasa khawatir. Efek-efek yang dapat ditimbulkan oleh media sosial tersebut tidak bisa dianggap remeh, sehingga perlu adanya aturan khusus yang tegas untuk menghadapi black campaign yang dilakukan di media sosial secara umum, salah satunya media sosial Instagram.

Mengingat penelitian mengenai black campaign telah beberapa kali dilakukan sebelumnya seperti: 1) Penelitian yang dilakukan oleh Adelia Fitri di tahun 2018, penelitian ini berfokus pada dampak media, khususnya media massa dan media sosial dalam kampanye menyambut pilihan presiden pada tahun 2019 silam sekaligus mengenai isu tantangan pelaksanaan kampanye dan pemilu; ${ }^{12}$ 2) Penelitian yang dilakukan oleh Bayhaqi Febriyan dan Nursiti di tahun 2017, penelitian ini berfokus pada jenis-jenis kampanye hitam yang secara spesifik terjadi di Kota Banda Aceh dalam rangka pemilihan kepala daerah sekaligus mengenai upaya pencegahan yang dilakukan untuk menanggulangi tindak pidana pemilu kampanye hitam (black campaign) yang

${ }^{12}$ Adelia Fitri, Dinamika Dan Tantangan Jelang Pemilu Presiden Tahun 2019, Kemudi: Jurnal Ilmu Pemerintahan, Vol. 3 Nomor 1, Agustus 2018, 116. secara umum terjadi.; ${ }^{13}$ dan 3) penelitian yang dilakukan oleh Yusa Djuyandi, Ari Ganjar Herdiansah dan Jafar Fikri Alkadrie di tahun 2018, penelitian ini berfokus pada bentuk pelaksanaan sosialisasi yang diselenggarakan terhadap adanya praktek black campaign yang berbahaya bagi keamanan Pemilihan Kepala Daerah di Provinsi Jawa Barat tahun 2018 silam yakni dengan menguraikan mengenai apa saja bentuk-bentuk dari praktek black campaign sekaligus dampaknya terhadap keamanan. ${ }^{14}$

Berdasarkan penelitian yang telah dilakukan sebelumnya, maka terdapat perbedaan yang menjadi fokus penelitian saat ini. Walaupun tema yang diambil memiliki keterkaitan yakni tentang black campaign, namun penelitian ini lebih menekankan pada tatanan hukum mengenai praktek black campaign, baik itu mengenai aturan hukumnya maupun mengenai akibat hukumya, terlebih lagi praktek black campaign yang dimaksud tersebut dilakukan melalui platform media sosial Instagram. Maka dapat dirumuskan permasalahan yang perlu dikaji, yaitu 1) bagaimana tatanan hukum Indonesia dalam mengatur black campaign?; 2) bagaimana akibat hukum terhadap black campaign yang dilakukan di platform media sosial Instagram?. Tujuan penelitian ini merupakan refleksi terhadap permasalahan tersebut, maka dari itu tujuan yang ingin dicapai yakni 1) untuk mengetahui tatanan hukum Indonesia dalam mengatur black campaign; 2) untuk mengetahui akibat hukum terhadap black campaign yang dilakukan di platform media sosial Instagram.

\footnotetext{
${ }^{13}$ Bayhaqi Febriyan \& Nursiti, Tindak Pidana Kampanye Hitam (Black Campaign) Dalam Penyelenggaraan Pemilihan Kepala Daerah Walikota Banda Aceh Tahun 2017, Jurnal Ilmiah Mahasiswa: Bidang Hukum Pidana, Vol. 1, Nomor 1, Agustus 2017, 60.

${ }^{14}$ Yusa Djuyandi, Ari Ganjar Herdiansah \& Jafar Fikri Alkadrie, Sosialisasi Dampak Negatif Black Campaign Terhadap Keamanan Pemilihan Kepala Daerah Tahun 2018 Di Provinsi Jawa Barat, Jurnal Pengabdian Kepada Masyarakat. Vol. 2, Nomor 7, Juli 2018, 582.
} 


\section{B. METODE PENELITIAN}

Penulisan ini adalah hasil penelitian dengan menggunakan metode yang sifatnya doktrinal, yaitu metode penelitian hukum normatif dengan spesifikasi penelitian deskriptif. Metode ini, lebih mengedepankan data sekunder sebagai data utamanya yaitu, bahan hukum primer berupa perundang-undangan terkait pelaksanaan pemilu dan kampanye di Indonesia, bahan hukum sekunder berupa buku-buku yang terkait, dan bahan hukum tersier berupa jurnal penelitian hukum dan artikel ilmiah lainnya. Data sekunder tersebut dikumpulkan melalui teknik studi kepustakaan dan dikelompokkan sesuai jenis bahan hukum.

Penelitian ini dituangkan dalam tulisan dengan menggunakan metode penulisan kualitatif. Metode kualitiatif ini menguraikan data-data ke dalam bentuk kalimat-kalimat menjadi sebuah paragraf yang teratur, logis, runtun (sistematis), tidak tumpang tindih dan efektif. Kemudian diambil kesimpulan secara deduktif sebagai jawaban mengenai hukum Indonesia dalam mengatur black campaign dan akibat hukum terhadap black campaign yang dilakukan di platform media sosial Instagram.

\section{HASIL DAN PEMBAHASAN}

\section{a. Tatanan Hukum Indonesia Dalam Mengatur Black Campaign}

Kampanye yang selalu dijadikan sebagai senjata dalam strategi berpolitik untuk mencapai tujuan politik yang dikehendaki, pada dasarnya terdiri dari 3 (tiga) jenis apabila dilihat dari segi substansi di dalam kampanye itu sendiri. Pertama, kampanye positif (positive compaign), yakni kampanye yang substansinya mengenai profil peserta pemilu yang sedang dikampanyekan dengan memuat berbagai informasi berupa promosi keunggulan dari yang bersangkutan atau segala hal yang dianggap positif, yang dikenal dengan istilah politik pencitraan. $^{15}$ Kedua, kampanye negatif (negative campaign), yakni kampanye yang substansinya membeberkan mengenai kesalahan dan kelemahan atau kekurangan yang ada pada diri lawan politik yang bersangkutan. Kelemahan yang dimaksud adalah merupakan fakta terhadap segala hal yang pernah terjadi sebelumnya atau bahkan sedang terjadi yang senyatanya ada dengan bukti rekam jejak negatif yang dapat dipertanggungjawabkan. Ketiga, kampanye hitam (black campaign), yakni kampanye yang substansinya adalah membeberkan segala sesuatu yang penuh dengan kebohongan, fitnah, omong kosong atau rumor yang sengaja diciptakan oleh lawan politik yang bersangkutan dengan tidak bersumber dan tidak dapat dipertanggungjawabkan. Hal inilah yang biasa dikenal dengan istilah pembunuhan karakter. $^{16}$

Menurut Dan Nimmo, jenis negative campaign dan black campaign merupakan jenis kampanye yang mempunyai persamaan dalam hal sifatnya, yakni menyerang pihak lain sebagai lawan politiknya atau yang dikenal dengan istilah attacking campaign. ${ }^{17}$ Hanya saja memang antara keduanya ada perbedaan yang signifikan. Seperti yang telah disebutkan di atas, negative campaign melakukan penyerangan terhadap kelemahan lawan politik, yang mana kelemahan tersebut merupakan sebuah fakta yang dapat dipertanggungjawabkan, sedangkan black campaign melakukan penyerangan terhadap lawan politik dengan sengaja menciptakan kebohongan atau fitnah yang tentu saja

15 Rafli Fadilah Achmad, Ancaman Pidana Bagi Intellectuel Dader Black Campaign: Studi Putusan Nomor 17/Pid.Sus/2014/Pn.Bul, Jurnal Hukum \& Pembangunan, Vol. 48, Nomor 4, Desember 2018, 701 http://Dx.Doi.Org/10.21143/Jhp.Vol48.No4.1799

${ }^{16}$ Rafli Fadilah Achmad, Ancaman Pidana Bagi Intellectuel Dader Black Campaign: Studi Putusan Nomor 17/Pid.Sus/2014/Pn.Bul, 701.

17 Dan Nimmo, Komunikasi Politik: Komunikator, Pesan Dan Media (Bandung: Rosda, 2009) 48-49. 
tidak dapat dipertanggungjawabkan demi mendapatkan keuntungan politik yang dikehendaki.

Pada dasarnya, adanya praktek negative campaign tidak dilarang dan tidak perlu dihindari, karena unsur negative yang dimaksudkan akan tergantung pada persepsi masing-masing masyarakat. Kemungkinan adanya unsur negative akan dirasakan apabila dilihat dari persepsi peserta pemilu yang bersangkutan itu sendiri maupun beserta pihak yang ditunjuk olehnya sebagai pelaksana dan tim kampanye, tetapi barangkali unsur negative yang ada justru tidak dirasakan oleh masyarakat sebagai pemilih karena masyarakat menganggap hal itu sebagai sesuatu yang baik berkat telah ditunjukannya suatu fakta yang diperoleh secara benar dan dapat dipertanggungjawabkan. ${ }^{18}$ Fakta yang ada, dapat dijadikan sebagai pertimbangan dalam memilih pada saat pemungutan suara. Hal ini dikarenakan masyarakat secara umum, berhak tahu rekam jejak para peserta pemilu sepenuhnya. Tidak hanya mengetahui sisi baiknya saja tetapi juga sisi buruknya terutama mengenai kelemahan atau kekurangannya sehingga nantinya dapat menilai sendiri berdasarkan persepsinya. Sebaliknya, justru masyarakat secara umum harus menghindari black campaign. Black campaign dilarang karena informasi yang sengaja dibeberkan adalah tuduhan yang sifatnya hanya omong kosong tidak berdasar atau mengada-ada saja. ${ }^{19}$

Faktanya adakalanya dalam masyarakat, alih-alih negative campaign berubah menjadi black campaign. Awalnya memang hanya berisi fakta yang senyatanya ada dan benar-benar terjadi yakni mengenai kelemahan atau kesalahan lawan politik yang bersangkutan, namun kemudian tidak segan diolah sedemikian rupa dengan ditambah bumbu kebohongan seperti tuduhan buruk tidak berdasar lalu semakin

18 Dan Nimmo, Komunikasi Politik: Komunikator, Pesan Dan Media, 48-49.

${ }^{19}$ Muhammad Rizaldi, Pro Dan Kontra Black Campaign Dalam Pemilihan Umum Di Indonesia, Fiat Justitia, Vol. 2 Nomor 2, Oktober 2014, 19. berkembang menjadi fitnah, rumor atau hoaks, agar menjadi suatu berita yang fenomenal dan menyebar secara luas dan cepat bahkan dengan mudahnya disangkutpautkan dengan unsur isu suku, agama, ras dan antar golongan (SARA). Mengingat SARA sebagai identitas kultural yang keberadaannya adalah merupakan sebuah realitas yang tidak dapat ditepis dan sekaligus sebagai sesuatu ciri khas yang unik serta menggambarkan kekayaan Indonesia. Sehingga isu SARA merupakan suatu hal yang sangat sensitif yang dapat membuat keadaan semakin memanas. ${ }^{20} \mathrm{Hal}$ tersebut dilakukan atas dasar dorongan sikap tidak mau kalah saing, sehingga memicu untuk berperilaku jahat yang memunculkan perasaan kekhawatiran, keresahan, kecemasan atau bahkan ketakutan secara berlebih terhadap kualitas lawan politik yang dihadapinya. Penyebaran black campaign yang dilakukan untuk menjatuhkan nama baik lawan politik yang dihadapinya dengan harapan yang bersangkutan dijauhi dan tidak disukai masyarakat secara umum sebagai pemilih sehingga nantinya tidak akan mendapatkan dukungan suara. ${ }^{21}$ Selain itu, bertujuan juga sebagai proses pembunuhan karakter dengan mengarahkan pada opini buruk terhadap lawan politik yang bersangkutan seperti yang telah disebutkan di atas dan sekaligus sebagai rencana untuk mengurangi peluang dipilihnya yang bersangkutan sebagai lawan politiknya sehingga dengan kata lain sebagai bentuk penyingkiran saingan yang dihadapinya. ${ }^{22}$

20 Nina Widyawati, Etnisitas Dan Agama Sebagai Isu Politik, Jurnal Masyarakat Dan Budaya, Vol.17 Nomor 2, Agustus 2015, 266.

21 Fauziyah \& Sri Praptianingsih, Pola Penyelesaian Sengketa Pemilihan Kepala Desa Di Kabupaten Bondowoso, Rechtsidee, Vol. 2, Nomor 1, Juni 2015, 18 http://dx.doi.org/10.21070/jihr.v2i1.8

22 La Januru, Analisis Wacana Black Campaign Pada Pilpres Tahun 2014 Di Media Kompas, Jawa Pos Dan Kedaulatan Rakyat, Jurnal Natapraja, Vol. 4 Nomor 2, Desember 2017, 193 https://doi.org/10.21831/jnp.v4i2.12625 
Praktek black campaign pada kenyataannya telah lama dilakukan dalam berkampanye politik. Hanya saja awal kemunculannya, black campaign masih dikenal dengan istilah smear campaign yang berarti kampanye kotor yakni kampanye dilangsungkan dengan cara yang kotor, buruk atau tidak baik. ${ }^{23}$ Hingga pada perkembangannya, smear campaign lebih dikenal dengan istilah black campaign seperti saat ini.

Persoalan mengenai definisi dari black campaign tidak diatur secara pasti di dalam undang-undang terkait pemilu di Indonesia, namun dalam penjelasan Pasal 69 huruf c Undang-Undang Nomor 10 Tahun 2016 Tentang Perubahan Kedua Atas Undang-Undang Nomor 1 Tahun 2015 Tentang Penetapan Peraturan Pemerintah Pengganti Undang-Undang Nomor 1 Tahun 2014 Tentang Pemilihan Gubernur, Bupati, Dan Walikota Menjadi Undang-Undang (UU 10/2016), dengan tegas menjelaskan bahwa perbuatan yang bentuknya berupa hasut, fitnah, adu domba antara para peserta pemilu, baik antara partai politik, perseorangan dan atau suatu kelompok masyarakat tertentu, termasuk ke dalam perbuatan yang selama ini dikenal dengan istilah black campaign. Sehingga apabila kampanye yang dilangsungkan mengandung perbuatan jahat atau dilakukan dengan cara buruk dan penuh kebohongan, maka hal itu sudah dapat dikategorikan sebagai black campaign, karena pada dasarnya, tidak ada bentuk khusus dari black campaign ini. Akan tetapi, meskipun tidak diatur secara pasti definisi maupun bentuk black campaign, undang-undang terkait pemilu di Indonesia mengatur mengenai hal-hal atau bentuk-bentuk perbuatan yang dilarang dalam pelaksanaan kampanye pemilu yang dapat mengindikasi adanya praktek black campaign. Seperti

23 Anwar Kholid \& Achmad Nurmandi, Media Sosial Dan Partisipasi Politik mahasiswa Selama Masa Pemilihan Presiden 2014, Jurnal Ilmu Pemerintahan \& Kebijakan Publik, Vol. 2 Nomor 1, Februari 2015, 30 http://dx.doi.org/10.18196/Jgpp.2015.0025 dalam Pasal 69 huruf b UU 10/2016, menyatakan bahwa dalam berkampanye politik tidak diperkenankan untuk melakukan penghinaan dengan membawa isu SARA calon gubernur beserta wakilnya, calon bupati beserta wakilnya, calon walikota beserta wakilnya, dan/atau partai politik. Isu SARA kian marak diikutsertakan dalam politik untuk dijadikan sebagai suatu hal yang mengindikasi terjadinya praktek black campaign. $^{24}$

Sejalan dengan itu, dalam Pasal 280 ayat (1) huruf $\mathrm{c}$ dan $\mathrm{d}$ Undang-Undang Nomor 7 Tahun 2017 Tentang Pemilihan Umum (UU 7/2017) jo. Pasal 69 ayat (1) huruf $\mathrm{c}$ dan d Peraturan Komisi Pemilihan Umum Nomor 28 Tahun 2018 tentang Perubahan atas Peraturan Komisi Pemilihan Umum Nomor 23 Tahun 2018 tentang Kampanye Pemilihan Umum (PKPU 28/2018) pun mengatur mengenai hal yang sama yaitu tentang hal-hal yang tidak diperkenankan atau larangan bagi pelaksana, peserta maupun tim kampanye dalam pelaksanaan kampanye pemilu yang mengindikasi munculnya praktek black campaign yakni berupa melakukan penghinaan terhadap seseorang termasuk melakukan penghinaan terhadap SARA, melakukan perbuatan hasut dan perbuatan adu domba antara para peserta pemilu baik antara partai satu dengan yang lainnya, antar perseorangan ataupun bahkan antar suatu masyarakat.

Praktek black campaign pada dasarnya sudah sejak dahulu dilakukan. Pada mulanya black campaign dilakukan dengan penyebaran gosip, isu atau rumor melalui media dari mulut ke mulut, sehingga dikenal dengan istilah whispering campaign, yang berarti kampanye melalui

24 Nindya Putri Edytya \& Galuh Dwi Novanda, Unsur Sara Dalam Kampanye: Sebuah Studi Komparasi Pilkada Sumatera Utara Dan Dki Jakarta, Seminar Nasional Hukum Universitas Negeri Semarang Vol. 4 Nomor 3, September 2018, 567. 
mulut ke mulut. ${ }^{25}$ Pada perkembangannya, black campaign tidak hanya selalu dilakukan melalui mulut ke mulut saja, tetapi sudah merambah melalui penggunaan media lain seperti media massa berupa media cetak maupun media elektronik yang masih tetap mendominasi hingga saat ini, dan kemudian lebih merambah lagi hingga pada pemanfaatan teknologi yang lebih canggih seperti media sosial yang real time dan tidak dapat dibatasi penggunaannya. $^{26}$

Media sosial menjadi salah satu metode efektif untuk berkampanye politik. Hal tersebut diatur dengan tegas dalam Pasal 275 ayat (1) huruf e UU 7/2017, yang menyatakan bahwa dalam berkampanye, dapat dilakukan dengan melalui metode media sosial. Sejalan dengan itu pula, hal yang sama mengenai pemanfaatan media sosial sebagai metode kampanye, diatur dalam Pasal 23 ayat (1) huruf e jo. Pasal 35 ayat (1) PKPU 28/2018.

Pemanfaatan media sosial dapat dirasakan secara signifikan dan menjadi semakin berkembang pesat khususnya di bidang politik. ${ }^{27}$ Media sosial memberikan banyak kemudahan, salah satunya untuk menjembatani hubungan komunikasi antara para tokoh politik dengan masyarakat khususnya dalam hal ini yang biasa disebut dengan istilah netizen. Netizen berasal dari gabungan kata Internet dan citizen (masyarakat) yang apabila diartikan adalah masyarakat pengguna aktif internet atau penghuni dunia maya. ${ }^{28}$ Hubungan antara keduanya menjadi lebih dekat meskipun

25 Arifuddin, Pengaruh Pesan Politik Caleg PKS Melalui Layanan Pesan Singkat (SMS) Terhadap Sikap Dan Perilaku Pemilih Dalam Pemilu Legislatif 2009 Di Kota Makassar, Jurnal Komunikasi Politik, Vol. 14, Nomor 1, September 2011, 28 http://dx.doi.org/10.31947/kjik.v1i3.300

${ }^{26}$ Bayhaqi Febriyan \& Nursiti, Tindak Pidana

Kampanye Hitam (Black Campaign) Dalam Penyelenggaraan Pemilihan Kepala Daerah Walikota Banda Aceh Tahun 2017, 55.

27 Adelia Fitri, Dinamika Dan Tantangan Jelang Pemilu Presiden Tahun 2019, 119.

28 Adelia Fitri, Dinamika Dan Tantangan Jelang Pemilu Presiden Tahun 2019, 119. kenyataannya terhalang perbedaan tempat dan jarak maupun waktu, sehingga tetap dapat berkomunikasi secara langsung. Hal inilah yang kemudian dimanfaatkan untuk ajang kampanye. Para tokoh politik berlomba-lomba mendekatkan diri dengan netizen untuk kemudian sekaligus menciptakan citra dirinya secara baik. Semua dilakukan hanya untuk menggiring opini masyarakat khususnya netizen ke arah positif sesuai yang mereka kehendaki.

Jenis media sosial sangat beragam. Salah satu media sosial yang popular dan diminati untuk berkampanye politik yakni Instagram. Instagram diciptakan oleh Kevin Systrom dan Mike Krieger pada 06 Oktober 2010 yang pada awal kemunculannya hingga saat ini memiliki pengguna paling banyak dan terpopuler di seluruh dunia karena hampir seluruh masyarakat menggemarinya. ${ }^{29}$ Instagram merupakan media sosial berbasis gambar yang memberikan layanan berbagi foto atau video secara online baik kepada pengguna lainnya maupun kepada media sosial lain. Selain itu, Instagram mempunyai beberapa fitur yang memudahkan para penggunanya, antara lain fitur followers atau pengikut, fitur berkirim pesan, fitur panggilan suara dan video, fitur efek untuk foto, fitur halaman popular dan masih banyak lainnya. $^{30}$

Instagram dianggap sebagai sarana untuk menyampaikan pesan politik sehingga sangat potensial dan berpeluang untuk memenangkan pemilu. Instagram dimanfaatkan untuk meningkatkan popularitas tokoh politik sebagai peserta pemilu dengan cara memperkenalkan sekaligus mempublikasikan ide atau gagasan dalam visi, misi, dan program unggulan, dokumentasi interaksi dengan masyarakat, hasil pencapaian di masa lalu

${ }^{29}$ Yuni Fadila Guchi, Persepsi Mahasiswa Hukum UMA Dalam Menyikapi Berita Hoax Di Instagram, Skripsi Fakultas Ilmu Sosial Ilmu Politik Universitas Medan Arena, 2019, 18.

30 Yuni Fadila Guchi, Persepsi Mahasiswa Hukum UMA Dalam Menyikapi Berita Hoax Di Instagram, 18. 
dan mempromosikan sikap kepemimpinan yang dimiliki tokoh politik yang bersangkutan. ${ }^{31}$ Instagram dinilai sangat efektif dalam penyebaran informasi secara luas sehingga mudah mendapatkan tanggapan secara cepat dan langsung. Selain itu Instagram dapat diakses dengan mudah oleh siapapun, kapanpun dan dimanapun, mengingat Instagram sangat digemari hampir seluruh kalangan masyarakat, sehingga berkampanye melalui Instagram tidak akan mengeluarkan banyak biaya dan memiliki banyak peminat dari semua kalangan. Tujuan utamanya demi menjaring pendukung dan relawan sebanyak-banyaknya yang berasal dari kalangan netizen.

Kenyataannya,

pemanfaatan Instagram sebagai media sosial dalam berkampanye seringkali disalahgunakan oleh banyak oknum yang tidak bertanggung jawab, mengingat Instagram memiliki jangkauan yang luas. ${ }^{32}$ Munculnya ambisi berlebihan untuk memenangkan pemilu seringkali dijadikan sebagai alasan untuk menyisipkan black campaign dalam media sosial khususnya Instagram. Tujuan black campaign melalui media sosial khususnya Instagram pada dasarnya tidak ada perbedaan dengan tujuan black campain secara umum, yakni sebagai bagian dari strategi politik untuk menjatuhkan lawan politiknya, mempengaruhi netizen dalam pengambilan keputusan agar muncul keraguan dari dalam diri netizen sebagai pemilih untuk kemudian meninggalkan pilihannya serta mengubah pilihannya pada tokoh politik lainnya tersebut. ${ }^{33}$

31 Indra Wahyu Krisnanto \& Fitriyah, Strategi Pemasaran Politik Pada Era Digital: Pemanfaatan Instagram Dalam Kampanye Politik Pada Pilgub DKI Jakarta 2017, Journal Of Politic And Government Studies, Vol 8, Nomor 3, Agustus 2019, 165

32 Dini Hidayanti Herpamudji, Strategi Kampanye Politik Prabowo-Hattadan Perang Pencitraan Di Media Massa Dalam Pemilu Presiden 2014, 18.

${ }^{33}$ Suyatno, Membungkam Kampanye Hitam, $1 \quad$ Maret, 2019 https://mediaindonesia.com/read/detail/220097-
Penyalahgunaan media sosial dalam bentuk black campaign tersebut sudah dapat dipastikan akan menimbulkan efek negatif yakni munculnya konflik dan berbagai kerugian dalam pelaksanaan pemilu. $^{34}$ Efek yang dapat ditimbulkan oleh media sosial tersebut tidak bisa dianggap remeh. Meskipun para tokoh politik sebagai peserta pemilu telah bersepakat satu sama lain untuk tidak saling menyebarkan black campaign, namun pada nyatanya black campaign masih marak direncanakan secara terstruktur dan dilakukan oleh oknum tertentu yang berkedok akun anonim (tanpa nama) yang disinyalir sebagai relawan dari tokoh politik yang bersangkutan. ${ }^{35}$ Oleh karena itu, pelaksanaan kampanye melalui media sosial di Indonesia diatur dalam undang-undang yeng bertujuan untuk mengurangi bahkan mencegah maraknya praktek black campaign.

Kampanye politik melalui metode media sosial diberikan batasan yakni hanya dapat membuat maksimal 10 (sepuluh) untuk setiap jenis platform media sosial. Hal ini diatur dalam Pasal 35 ayat (2) PKPU 28/2018. Ini berarti tidak hanya berlaku bagi platform media sosial Instagram saja. Akan tetapi juga berlaku bagi media sosial lainnya seperti Facebook, Twitter, Youtube, Whatsapp, Line dan lainlain. Kemudian tidak cukup sampai disitu saja, menurut Pasal 36 PKPU 28/2018, masih ada prosedur lain yang harus dipenuhi terkait akun media sosial yang akan digunakan untuk berkampanye, yakni akun media sosial yang dimaksud harus secara resmi didaftarkan oleh pelaksana kampanye paling lambat 1 (satu) hari sebelum masa kampanye dimulai.

membungkam-kampanye-hitam (diakses 5 Januari 2020).

${ }^{34}$ Galuh A. Savitri, Media Sosial Dan Black Campaign, 12 Juli, 2018, https://binus.ac.id/malang/2018/07/media-sosialdan-black-campaign/ (diakses 3 Januari 2020).

${ }^{35}$ Rafli Fadilah Achmad, Ancaman Pidana Bagi Intellectuel Dader Black Campaign: Studi Putusan Nomor 17/Pid.Sus/2014/Pn.Bul, 707. 
Platform media sosial memegang peranan penting dalam kampanye politik. Hal ini dikarenakan Badan Pengawas Pemilu (Bawaslu) tidak hanya bekerja sama dengan Kementerian Komunikasi dan Informatika (Kominfo) dan Badan Siber dan Sandi Negara (BSSN) tetapi turut bekerja sama pula dengan platform media sosial termasuk di dalamnya platform media sosial Instagram. ${ }^{36}$ Akun media sosial khusus bagi calon presiden dan wakil presiden, wajib didaftarkan kepada Komisi Pemilihan Umum (KPU), yang prosedur pendaftarannya wajib menggunakan formulir model "FK-MEDSOS.PRES". Begitupun bagi akun media sosial peserta pemilu anggota DPR, wajib didaftarkan kepada KPU, namun dengan menggunakan formulir pendaftaran yang berbeda yakni model "FK-MEDSOS.DPR". Pendaftaran akun media sosial wajib dilakukan kepada KPU Provinsi atau Komisi Independen Pemilihan (KPI) Aceh, bagi akun media sosial khusus peserta pemilu anggota DPD dengan menyertakan formulir pendaftaran model "FK-MEDSOS.DPD" dan juga bagi akun media sosial khusus peserta pemilu anggota DPRD Provinsi dengan menyertakan formulir pendaftaran "FKMEDSOS.DPRD-PROV". Sedangkan bagi peserta pemilu anggota DPRD Kabupaten/Kota, akun sosial yang dimaksud wajib didaftarkan kepada KPU atau KPI Kabupaten/Kota, dengan menggunakan formulir pendaftaran Model "FK-MEDSOS.DPRD-KAB/KOTA".

Model formulir pendaftaran akun media sosial tersebut di atas memang sekilas terlihat berbeda-beda, karena adanya beberapa model formulir pendaftaran yang disediakan, namun pada dasarnya keseluruhannya tetap memuat hal yang sama. Muatan formulir pendaftaran akun media sosial, pada intinya harus mengisi jenis aplikasi media sosial yang digunakan beserta nama akun dan alamat url akun

${ }^{36}$ Andrian Pratama Taher, Bawaslu Jelaskan Soal Kampanye Iklan Di Medsos, 8 Februari, 2007, https://tirto.id/bawaslu-jelaskan-soal-kampanyeiklan-di-medsos-ciDd (diakses 14 Januari 2020). tersebut. Nama akun dan alamat url harus diisi sesuai dengan jumlah akun media sosial yang senyatanya dimiliki dengan tetap memperhatikan aturan yang telah diatur yakni maksimal 10 (sepuluh) akun untuk setiap jenis aplikasinya. Perbedaannya hanya pada adanya nama pasangan calon, nama calon anggota atau nama partai politik beserta nomor urut yang harus diisi sesuai dengan jenisnya masingmasing. Kemudian pendaftaran akun media sosial dengan formulir pendaftaran tersebut wajib dibuat 4 (empat) rangkap yang ditujukan kepada; a.KPU, KPU Provinsi/KIP Aceh dan KPU/KIP Kabupaten/Kota, sesuai dengan tingkatannya; b.Bawaslu, Bawaslu Provinsi dan Bawaslu Kabupaten/Kota, sesuai dengan tingkatannya; c.Kepolisian Negara Republik Indonesia, sesuai dengantingkatannya; dan d.Pasangan calon, partai politik atau gabungan partai politik, dan calon anggota DPD sebagai arsip.

Akun media sosial yang sudah didaftarkan secara resmi dan sudah siap untuk digunakan sebagai media dalam berkampanye politik, paling sedikitnya memuat materi mengenai keunggulan visi, misi yang diciptakan dan juga program rencana yang akan dijalankan oleh peserta pemilu. Muatan yang dimaksud dapat dituangkan melalui bentuk yang berupa teks tulisan, audio maupun gambar atau gabungan antara ketiganya yang sifatnya naratif, grafis, karakter, interaktif atau tidak interaktif, dan yang dapat diterima melalui perangkat penerima pesan. Hal ini diatur secara tegas dalam Pasal 35 ayat (3) dan (4) PKPU 28/2018.

Selain melalui akun media sosial khusus yang terdaftar secara resmi, kampanye melalui media sosial juga dapat dilakukan dengan metode pemberitaan, penyiaran dan iklan kampanye sebagai bentuk penyampaian pesan kampanye pemilu oleh peserta pemilu kepada masyarakat, yang diatur tegas dalam UU 7/2017 dan PKPU 28/2018. Mengenai aturan muatan pemberitaan, penyiaran dan iklan kampanye melalui media sosial tidak 
jauh berbeda dengan aturan dalam akun media sosial khusus terdaftar, yakni materi pemberitaan, penyiaran dan iklan kampanye paling sedikitnya memuat materi mengenai keunggulan visi, misi yang diciptakan dan juga program rencana yang akan dijalankan oleh peserta pemilu. Muatan yang dimaksud dapat dituangkan melalui bentuk yang berupa teks tulisan, audio maupun gambar atau gabungan antara ketiganya yang sifatnya naratif, grafis, karakter, interaktif atau tidak interaktif, dan yang dapat diterima melalui perangkat penerima pesan dengan keharusan untuk tetap mematuhi ketentuan peraturan perundangundangan dan kode etik periklanan, yakni antara lain adanya larangan muatan iklan kampanye yang bentuknya tayangan atau penulisan berbentuk berita dalam media sosial, serta adanya pembatasan durasi dalam iklan kampanye melalui media sosial yang apabila diakumulasikan, dalam 1 (satu) spot berdurasi maksimal 30 (tiga puluh) detik untuk setiap harinya. Mengenai pengaturan dan penjadwalan pemasangan iklan kampanye diatur sepenuhnya oleh platform media sosial yang bersangkutan. Kampanye melalui iklan media sosial diperkenankan melalui akun media sosial khusus yang telah terdaftar, untuk dapat menggunakan program iklan $(a d s)$ platform media sosial yang bersangkutan. ${ }^{37}$

Berdasarkan UU 7/2017 dan PKPU 28/2018, platform media sosial sebagai wadah iklan kampanye yang berbentuk komersial atau layanan masyarakat harus berlaku adil dan berimbang dengan memberi kesempatan yang sama setiap peserta pemilu, sekaligus menentukan standar tarif iklan kampanye komersial yang berlaku sama untuk setiap peserta pemilu yang berdasarkan aturannya, tarif iklan kampanye layanan masyarakat harus lebih rendah daripada tarif iklan kampanye komersial. Platform media sosial pun harus bersikap hati-hati, untuk tidak melakukan

${ }^{37}$ Andrian Pratama Taher, Bawaslu Jelaskan Soal Kampanye Iklan Di Medsos. pelanggaran-pelanggaran dalam melaksanakan fungsinya sebagai media untuk pemberitaan, penyiaran dan iklan kampanye yakni antara tidak diperkenankan menjual pemblokiran segmen (blocking segment) dan/atau pemblokiran waktu (blocking time) untuk kepentingan kampanye pemilu, tidak diperkenankan pula menerima program sponsor dalam format atau segmen apapun untuk kepentingan iklan kampanye pemilu termasuk untuk tidak diperkenankan menjual spot iklan yang tidak dimanfaatkan oleh salah satu peserta pemilu kepada peserta pemilu yang lain dan lain-lain.

Kampanye pemilu yang dilakukan melalui media sosial dalam bentuk pemberitaan, penyiaran dan iklan kampanye, jangka waktu pelaksanaanya selama 21 (dua puluh satu) hari dan berakhir sampai dengan dimulainya masa tenang. Sehingga, selama masa tenang media sosial dilarang menyiarkan berita, iklan, rekam jejak, citra diri peserta pemilu, dan/atau bentuk lainnya termasuk juga tagar (tanda pagar) yang mengarah kepada kepentingan kampanye yang menguntungkan atau merugikan peserta pemilu. Hal ini diatur secara tegas, baik dalam Pasal 276 ayat (2) UU 7/2017 jo. Pasal 24 ayat (2) PKPU 28/2018 dan sejalan dengan aturan mengenai adanya kewajiban untuk menutup akun media sosial khusus sebagai wadah berkmpanye politik pada hari terakhir masa kampanye sebelum masa tenang, sesuai yang diatur dalam Pasal 36 ayat (6) PKPU 28/2018. Ini merupakan salah satu alasan adanya kerja sama antara Bawaslu dengan platform media sosial yang bersangkutan. Masa tenang tidak menutup kemungkinan bersih dari black campaign, justru masa tenang rawan dimanfaatkan oknum tertentu untuk mewujudkan terjadinya praktek black campaign khususnya melalui iklan kampanye. Pada kondisi seperti ini, Bawaslu berwenang untuk memerintahkan platform media sosial yang bersangkutan untuk menonaktifkan akun yang mengandung kampanye khususnya dalam 
hal ini media sosial Instagram, tanpa harus melalui Kominfo terlebih dahulu. Tindakan kerja sama tersebut dilakukan dalam rangka memperketat pengawasan praktek black campaign dalam masa tenang.

\section{b. Akibat Hukum Terhadap Black Campaign Yang Dilakukan Di Platform Media Sosial Instagram}

Black campaign melalui media sosial, khususnya Instagram bertujuan sebagai strategi untuk menyerang, menjatuhkan nama baik lawan politik yang dihadapinya dengan harapan yang bersangkutan tidak akan mendapat simpati dari masyarakat sehingga dapat dipastikan pula tidak akan mendapatkan dukungan suara yang cukup. ${ }^{38}$ Hal tersebut dikenal sebagai bentuk politik pembunuhan karakter. ${ }^{39}$ Masyarakat secara umum, khususnya netizen dapat terpengaruh dengan adanya isu-isu yang tersebar di postingan media sosial Instagram, yang kemudian secara sadar membentuk persepsi buruk terhadap tokoh politik yang bersangkutan. Meskipun black campaign seringkali digunakan sebagai senjata utama dalam strategi berkampanye politik, tetapi pada kenyataannya tidak selalu menjadi jaminan bahwa praktek black campaign merupakan strategi yang ampuh dan efektif untuk mendongkrak perolehan dukungan suara. Akan tetapi, sudah tentu keberadaan black campaign dapat memunculkan keonaran yang dapat meresahkan dan mengkhawatirkan masyarakat umum secara luas, tidak hanya dari kalangan netizen saja.

Munculnya keresahan dan kekhawatiran masyarat bukanlah tanpa sebab. Hal ini didasari karena adanya bentuk penerimaan dari suatu media oleh masyarakat. Pada dasarnya terdapat perbedaan dalam media penerimaan yang bergantung pada faktor yang dilatarbelakangi oleh jenis media, rentang

38 Fauziyah \& Sri Praptianingsih, Pola Penyelesaian Sengketa Pemilihan Kepala Desa Di Kabupaten Bondowoso, 18.

39 La Januru, Analisis Wacana Black Campaign Pada Pilpres Tahun 2014 Di Media Kompas, Jawa Pos Dan Kedaulatan Rakyat, 193. usia, pandangan, kecenderungan minat dan bakat, sosial budaya, keahlian dan kompetensi serta latar belakang lainnya. ${ }^{40}$ Media sosial Instagram cukup populer di kalangan netizen yang rentang usianya mayoritas 18-34 tahun, yang berarti usianya masuk ke dalam kategori remaja akhir hingga dewasa awal. Bagi masyarakat yang rentang usianya masuk dalam kategori lansia hingga manula, masyarakat miskin, masyarakat yang tingkat pendidikannya rendah dan masyarakat yang belum melek teknologi khususnya media sosial Instagram, menggunakan media eletronik seperti televisi, radio, atau media cetak sebagai media dominan yang diandalkan dalam mendapatkan sumber informasi. ${ }^{41}$

Ironisnya, di masa sekarang media sosial khususnya Instagram justru difungsikan sebagai sumber utama informasi, sehingga membuat media elektronik dan media cetak mulai merambah ke media sosial dalam menyebarkan dan mendapatkan informasi. Hal ini menunjukkan media sosial secara tidak langsung difungsikan sebagai media dalam bertukar informasi. Apapun jenis informasi yang sumbernya dari media sosial, selalu dapat menjadi andalan utama bagi jurnalis, apalagi yang selalu menyangkut opini publik. ${ }^{42}$ Banyaknya informasi yang ada di dalam media sosial, tentu saja sangat mempermudah tugas jurnalis. Hanya cukup dengan mengandalkan sumber informasi dari media sosial, dengan mudahnya jurnalis dapat menemukan ide pembuatan berita bagi media elektronik maupun media cetak. Media elektronik dan media cetak seolaholah terpancing dan ikut terpengaruh dengan yang ada di media sosial.

40 Antar Venus, Manajemen Kampanye; Panduan Teoritis Dan Praktis Dalam Mengefektifkan Kampanye Komunikasi, 86-89.

41 Antar Venus, Manajemen Kampanye; Panduan Teoritis Dan Praktis Dalam Mengefektifkan Kampanye Komunikasi, 86-89.

Sumartono, Konstruksi Makna Media Sosial Bagi Anggota DPRD Kota Padang, Al'Adalah, Vol. 20, Nomor 1, Mei 2017, 23. 
Pemanfaatan media sosial sebagai sumber utama informasi memang menguntungkan dan memberikan efek yang baik dalam hal tugas dan kinerja jurnalis. Namun daripada itu, pemanfaatan media sosial sebagai sumber utama informasi dapat menjadi masalah sehingga berita yang dihasilkan penuh dengan kebohongan dalam hal apabila tidak dipastikan kebenarannya melalui pengverifikasian kebenaran informasi dari media sosial yang bersangkutan. Media dalam penyebaran dan pemberian informasi yang seharusnya mempunyai kualitas yang baik dan akurat, justru bisa berubah menjadi media penyebaran berita bohong. Hal ini pun berlaku bagi informasi pemilu khusunya kampanye. Apabila informasi yang diterima masyarakat adalah penuh kebohongan atau fitnah dalam hal ini tergolong sebagai black campaign, maka masyarakat akan mengantongi informasi yang tidak benar dan tidak berdasar. Padahal media elektronik dan media cetak yang masih mendominasi dalam program kampanye seharusnya bersifat objekif dalam penyebaran informasi, dapat memberikan pencerahan, menunjukkan dan menyampaikan yang senyatanya benar dan jelas baik dalam hal sisi baik maupun sisi buruk sekalipun. Sehingga, media tidak menunjukkan sikap menghakimi atau memihak salah satu antara tokoh politik sebagai peserta pemilu yang pada akhirnya memungkinkan masyarakat terjebak pada pilihannya. ${ }^{43}$ Bagaimana tidak, jenis media baik itu media sosial, maupun media cetak atau media elektronik seluruhnya didominasi dan difungsikan sebagai penyebaran black campaign. Ironisnya, peristiwa saling serang dengan muatan black campaign antara tokoh politik satu dengan yang lainnya tidak henti dilakukan, sehingga hal inilah yang meresahkan dan mengkhawatirkan masyarakat secara

43 Ade Tuti Turistiati, Fenomena Black Campaign Dalam Pemilihan Kepala Daerah 2015, Transparansi: Jurnal Ilmiah Ilmu Administrasi, Vol. VIII, Nomor 2, September 2016, 211 https://doi.org/10.31334/trans.v8i2.72 umum, tidak hanya bagi netizen saja, seakan-akan tertanam di pikiran bahwa tokoh politik seluruhnya buruk, tidak ada sisi baiknya sama sekali.

Baik kampanye yang dilakukan dengan orasi politik secara jelas dan terbuka maupun black campaign yang dilakukan melalui media, keduanya menimbulkan pengaruh, tidak hanya bagi tokoh politik sebagai peserta pemilu saja, tetapi juga dinilai lebih menimbulkan pengaruh terhadap masyarakat umum sebagai pemilih. $^{44}$ Menurut Anthony Downs, pilihan politik masyarakat tidak selalu berpatokan pada sedikit banyaknya informasi yang dimiliki dan dipahami, tetapi juga dalam prosesnya dipengaruhi oleh kemampuan masyarakat untuk mengelola suatu informasi tersebut, yang dikenal dengan istilah contextual knowledge. Contextual knowledge yang dimaksud adalah perihal politik, yang tidak dimiliki sebagian besar masyarakat Indonesia sehingga belum berkapasitas baik dalam hal itu. ${ }^{45}$ Informasi politik yang dilakukan secara jelas dan terbuka belum tentu dapat dikelola dan diolah oleh masyarakat umum sehingga pada umumnya masyarakat lebih menaruh minat dan lebih tertarik untuk fokus pada isu-isu politik mengenai tokoh politik yang bersangkutan dibandingkan visi dan misi yang

44 Reza Maulana Alamsyah \& Prahastiwi Utari, Pengaruh Kampanye Hitam (Black Campaign) Pada Pemilih Pemula (Studi Eksperimen Pengaruh Kampanye Hitam (Black Campaign) Pada Kampanye Calon Presiden Dan Calon Wakil Presiden Pemilu 2014 Melalui Media Sosialisasi Dan Diskusi Terhadap Pemahaman Pemilihan Umum Dikalangan Pemilih Pemula Di SMS Negeri 1 Purworejo), Jurnal Komunikasi Massa: Jurnal Ilmu Komunikasi Universitas Sebelas Maret, Vol. 1, 2016, 16.

45 Reza Maulana Alamsyah \& Prahastiwi Utari, Pengaruh Kampanye Hitam (Black Campaign) Pada Pemilih Pemula (Studi Eksperimen Pengaruh Kampanye Hitam (Black Campaign) Pada Kampanye Calon Presiden Dan Calon Wakil Presiden Pemilu 2014 Melalui Media Sosialisasi Dan Diskusi Terhadap Pemahaman Pemilihan Umum Dikalangan Pemilih Pemula Di SMS Negeri 1 Purworejo), 16. 
disampaikan oleh tokoh politik. Hal ini dikarenakan masyarakat cenderung tidak fokus dan tidak peduli mengenai asal sumber informasi yang diperoleh. ${ }^{46}$

Sehingga, sangat jelas bahwa praktek black campaign melalui media sosial, khusunya Instagram menimbulkan efek yang lebih dari sekedar berita bohong dan jatuhnya nama baik para tokoh politik saja, tetapi juga berefek bagi masyarakat dalam hal hak untuk mendapatkan suatu informasi secara akurat dan objektif. Tindakan tersebut, tentu menimbulkan akibat hukum. Black campaign temasuk tindak pidana pemilu, yaitu tindak pidana pelanggaran dan/atau kejahatan yang bentuknya diatur dalam UU 7/2017 sebagaimana Pasal 1 angka 2 Peraturan Mahkamah Agung Nomor 1 Tahun 2018 tentang Tata Cara Penyelesaian Tindak Pidana Pemilihan dan Pemilihan Umum (Perma 1/2018). Selain itu, black campaign yang dilakukan melalui platform media sosial ini sangat erat kaitannya dengan pemanfaatan teknologi yang termasuk dalam tindak pidana siber (cyber crime), sehingga berlaku pula Undang-Undang Nomor 19 Tahun 2016 Tentang Perubahan Atas Undang-Undang Nomor 11 Tahun 2008 Tentang Informasi Dan Transaksi Elektronik (UU 19/2016) dalam prosesnya. ${ }^{47}$

UU 7/2017 mengatur mengenai "Ketentuan Pidana Pemilu" sebagai akibat hukum dalam hal apabila terjadi pelanggaran terhadap larangan dalam berkampanye termasuk pula di dalamnya praktek black campaign melalui media sosial. Seperti yang telah diuraikan di atas, mengenai istilah maupun definisi black campaign tidak diatur secara tegas dalam UU 7/2017, namun berdasarkan hal-hal yang dilarang khususnya dalam Pasal 280

${ }^{46}$ Andre Setiawan, Analisis Yuridis Terhadap Berita Bohong (Hoax) Yang Beredar Di Media Sosial Berdasarkan Hukum Positif, Dinamika Hukum: Jurnal Ilmiah Ilmu Hukum, Vol. 25, Nomor 6, Agustus 2019, 28.

47 Barda Nawawi Arief, Tindak Pidana Mayantara: Perkembangan Kajian Cybercrime Di Indonesia, (Jakarta: Rajagrafindo Persada, 2006), 36. ayat (1) huruf d undang-undang tersebut, dapat disamakan dengan bentuk black campaign yang ada dalam penjelasan Pasal 69 huruf c UU 10/2016 mengenai perbuatan yang bentuknya hasut, fitnah, adu domba antara para peserta pemilu, baik antara partai politik, perseorangan dan atau suatu kelompok masyarakat tertentu, termasuk ke dalam perbuatan yang selama ini dikenal dengan istilah black campaign. Selain itu, Pasal 280 ayat (1) huruf c berkaitan pula dengan Pasal 69 huruf b UU 10/2016 sebagai bentuk perbuatan yang dapat mengindikasi adanya praktek black campaign yakni penghinaan dengan membawa isu SARA calon gubernur beserta wakilnya, calon bupati beserta wakilnya, calon walikota beserta wakilnya, dan/atau partai politik.

Pada kondisi tersebut di atas, UU 7/2017 memberlakukan sanksi yang diatur dalam Pasal 521 mengenai larangan pemilu yang jenisnya sebagaimana diatur dalam Pasal 280 ayat (1), yakni bagi pelaksana, peserta dan atau tim kampanye sebagai subjek yang melalukan tindakan yang antara lain berupa perbuatan hasut dan adu domba, serta menghina seseorang kaitannya dengan SARA yang mengindikasi adanya praktek black campaign, diancam dengan pidana penjara paling lama 2 (dua) tahun dan denda paling banyak Rp24.000.000,00 (dua puluh empat juta rupiah). Praktek black campaign yang dimaksud dilakukan dalam metode kampanye sebagaimana diatur dalam Pasal 275 ayat 1 UU 7/2017, sehingga tidak ada perbedaan dalam hal pemberian sanksinya. Oleh karena itu, black campaign yang dilakukan melalui seluruh media sosial khususnya dalam hal ini Instagram, diancam pidana yang sama dengan black campaign yang dilakukan melalui metode kampanye lainnya seperti melalui pertemuan terbatas, penyebaran bahan kampanye kepada umum, rapat umum, maupun dalam bentuk lain sesuai pasal yang bersangkutan tersebut.

Sementara itu, selain diberlakukan UU 7/2017, dengan adanya pemanfaatan kecanggihan teknologi khususnya media 
sosial Instagram dalam black campaign termasuk ke dalam tindak pidana siber sebagaimana yang telah diuraikan di atas, sehingga dapat dijerat dengan memberlakukan UU 19/2016. Berdasarkan Pasal 45 ayat (3) jo. Pasal 27 ayat (3), bagi setiap orang yang dengan sengaja dan dengan tanpa hak membagikan dan/atau meneruskan atau membagikan kembali dan/atau membuat dapat diaksesnya informasi elektronik dan/atau dokumen elektronik yang memiliki muatan penghinaan dan/atau pencemaran nama baik, dipidana dengan pidana penjara paling lama 4 (empat) tahun dan/atau denda paling banyak Rp750.000.000,00 (tujuh ratus lima puluh juta rupiah). Selain itu mengenai bentuk perbuatan pelanggaran SARA sebagai bahan untuk berkampanye politik diatur dalam Pasal 45A ayat (2) jo. Pasal 28 ayat (2), yakni setiap orang yang dengan sengaja dan tanpa hak menyebarkan informasi yang ditujukan untuk menimbulkan rasa kebencian atau permusuhan individu dan/atau kelompok masyarakat tertentu berdasarkan atas suku, agama, ras, dan antar golongan (SARA), dipidana dengan pidana penjara paling lama 6 (enam) tahun dan/ atau denda paling banyak Rp 1. 000.000. 000,00 (satu miliar rupiah).

Pengaturan tindak pidana tertentu dalam UU 19/2016 dapat disepadankan dengan tindak pidana pemilu sebagaimana diatur dalam UU 7/2017. Dapat diberlakukannya UU 7/2017 dan UU 19/2016 dalam penyelesaian permasalahan black campaign melalui media sosial Instagram, memunculkan adanya dualisme undang-undang. Selain itu pula, masih ada kerancuan dalam UU 7/2017, salah satunya dalam hal subjek tindak pidana pemilu. Subjek tindak pidana dalam UU 19/2016 adalah setiap orang. Setiap orang yang dimaksud dalam UU 19/2016 adalah sebagaimana yang diatur dalam Pasal 1 angka 21, yakni orang perseorangan, baik warga negara Indonesia, warga negara asing, maupun badan hukum. Sedangkan subjek tindak pidana dalam UU 7/2017 diatur dan disebutkan secara eksplisit dalam Pasal 280 ayat (1), yakni larangan kampanye pemilu diberlakukan kepada pelaksana, peserta, dan tim kampanye pemilu. "Peserta" yang dimaksud dalam hal ini tidak jelas, apakah mengarah pada peserta pemilu atau peserta kampanye. Kedua istilah tersebut baik peserta pemilu maupun peserta kampanye mempunyai perbedaan yang signifikan. Peserta pemilu berdasarkan Pasal 1 angka 27 adalah partai politik untuk pemilu anggota DPR, anggota DPRD Povinsi, anggota DPRD Kabupaten/Kota, perseorangan untuk pemilu anggota DPD, dan pasangan calon yang diusulkan oleh partai politik atau gabungan partai politik untuk pemilu presiden dan wakil presiden. Sedangkan peserta kampanye adalah anggota masyarakat secara umum yang ikut serta dalam kampanye pemilu.

Menurut Puteri Hikmawati, yang dimaksud "peserta" di dalam Pasal 280 ayat (1) UU 7/2017 adalah peserta kampanye, bukan peserta pemilu. Hal ini dapat ditafsirkan dari Pasal 268 ayat (2), bahwa kampanye pemilu diikuti oleh peserta kampanye, dan peserta kampanye pemilu terdiri atas anggota masyarakat sebagaimana diatur Pasal $273 .{ }^{48}$ Selain itu pula, dalam UU $7 / 2017$ bagian ke 10 (sepuluh) mengenai "Pengawasan atas Pelaksanaan Kampanye Pemilu" antara Pasal 307 sampai pada Pasal 324, Bawaslu melakukan pengawasan atas pelaksanaan kampanye pemilu terkait pelanggaran kampanye yang lebih difokuskan terhadap pelaksana kampanye, tim kampanye dan peserta kampanye. Hal ini menunjukkan bahwa berdasarkan pasal tersebut, setiap anggota masyarakat selaku peserta kampanye dapat dikenakan tindak pidana pemilu berdasarkan UU 7/2017.

Namun, faktanya selama ini, "peserta" dalam Pasal 280 ayat (1) UU

48 Puteri Hikmawati, Penafsiran terhadap Subjek Pelanggaran Kampanye dalam UU No. 7 Tahun 2017 dan Ancaman Sanksi Pidananya, Parliamentary Review, Vol. 1, Nomor 1, Maret 2019, 7. 
7/2017 selalu ditafsirkan sebagai peserta pemilu. Seakan-akan UU 7/2017 hanya berlaku bagi pihak yang berhubungan langsung dengan pemilu yakni pelaksana kampanye, peserta pemilu dan tim kampanye saja. Salah satu contoh, Rahmat Bagja selaku anggota Bawaslu, mengemukakan bahwa larangan dan sanksi di UU 7/2017 hanya ditujukan kepada pelaksana kampanye, peserta, dan/atau tim kampanye. Peserta yang dimaksud dalam hal ini menurutnya adalah peserta pemilu. Lebih lanjut, Rahmat Bagja menuturkan bahwa pada dasarnya jangkauan pidana pemilu itu tidak sampai ke relawan, sehingga apabila orang per orang secara umum misalnya relawan atau simpatisan, yang tentu saja bukan termasuk pelaksana kampanye, peserta pemilu dan/atau tim kampanye melakukan black campaign melalui media sosial tidak dapat dijerat dengan UU 7/2017, melainkan dapat dijerat dengan UU 19/2016. ${ }^{49}$ Edward Fritz Siregar selaku anggota Bawaslu pun berpendapat demikian. Menurutnya, yang dianggap subjek tindak pidana pemilu tersebut adalah para pihak yang berhubungan langsung dengan pemilu dan calon yang akan dipilih. $^{50}$

Kemudian, Titi Anggraini selaku Pengurus Harian Direktur Eksekutif Perkumpulan Pemilu dan Demokrasi (Perludem) menilai bahwa yang larangan dalam UU 7/2017 berlaku bagi pelaksana kampanye, peserta pemilu dan tim kampanye. Aturan dalam UU 7/2017 tidak menjangkau orang yang fanatik terhadap peserta pemilu tertentu dalam hal ini dapat diartikan masyarakat pada umumnya sebagai peserta kampanye. ${ }^{51}$ Sejalan dengan

${ }^{49}$ Amalia Salabi, Perihal Kampanye Negatif dan Kampanye Hitam Apa Bedanya?, 9 Oktober, 2018 https://rumahpemilu.org/perihal-kampanyenegatif-dan-kampanye-hitam-apa-bedanya/, (diakses 29 Januari 2020).

50 Puteri Hikmawati, Penafsiran terhadap Subjek Pelanggaran Kampanye dalam UU No. 7 Tahun 2017 dan Ancaman Sanksi Pidananya, 6.

51 Mula Akmal \& Kiswondari, Masih Kampanye di Medsos Bisa Dijerat Pidana, 15 April, 2019 itu, Mahfud MD yang merupakan Mantan Ketua Mahkamah Konstitusi (MK), ketika menyikapi kasus black campaign oleh ketiga emak-emak di Karawang yang videonya tersebar melalui media sosial, tidak terjerat UU 7/2017. Menurutnya, hal itu sudah tepat, dikarenakan ketiga emakemak yang bersangkutan bukan merupakan bagian partai politik seperti pasangan calon, calon legislatif atau tim pemenangan sehingga tidak dapat dijerat pidana pemilu dengan UU 7/2017, tetapi justru melanggar UU $19 / 2016 .^{52}$

Bagaimanapun, black campaign melalui media sosial khususnya Instagram tidak dapat ditoleransi. Segala sesuatu yang tidak sesuai fakta, pencemaran nama baik dan fitnah termasuk kategori black campaign, sehingga pelakunya harus ditindak secara tegas dan harus dihukum. Penafsiran mengenai subjek tindak pidana pemilu khususnya peserta memang masih beragam, apakah peserta yang dimaksud di dalam Pasal 280 ayat (1) UU 7/2017 tersebut merupakan peserta kampanye atau peserta pemilu, atau bahkan berlaku bagi keduanya. Hal ini dikarenakan keduanya, baik antara peserta kampanye maupun peserta pemilu merupakan istilah yang mempunyai arti yang berbeda. Mengingat praktek black campaign tidak selalu dilakukan oleh peserta pemilu atau yang berhubungan langsung dengan pemilu saja, akan tetapi masyarakat secara umum sebagai peserta kampanye pun berpeluang untuk melakukan tindakan praktek black campaign. Selain itu, adanya dualisme undang-undang yang dapat menjerat tindakan black campaign melalui media sosial khususnya Instagram yakni UU 7/2017 dan UU 19/2016. Sehingga kenyataan yang ada saat ini, dalam

https://nasional.sindonews.com/read/1395865/12/ma sih-kampanye-di-medsos-bisa-dijerat-pidana1555289961 (diakses 29 Januari 2020).

52 Andrian Pratama Taher, Mahfud MD Benarkan 3 Emak-emak Relawan Pepes Tak Langgar UU Pemilu, 27 Februari, 2019, https://tirto.id/mahfud-md-benarkan-3-emak-emakrelawan-pepes-tak-langgar-uu-pemilu-dhTH (diakses 28 Januari 2020). 
pelaksanaannya apabila anggota masyarakat secara umum yang tidak langsung berhubungan dengan kepentingan pemilu dianggap melakukan black campaign melalui media sosial, maka tidak dapat berlaku UU 7/2017 baginya, melainkan otomatis dikenai ancaman sanksi yang lebih berat dengan menggunakan UU 19/2016. Sedangkan apabila yang melakukan black campaign tersebut adalah orang yang mempunyai hubungan langsung dengan pemilu dalam hal ini misalnya peserta pemilu, maka dijerat dengan UU 7/2017. Hal ini tentunya menimbulkan ketidakpastian dan ketidakadilan bagi masyarakat. $^{53}$ Oleh karena itu, persepsi mengenai subjek tindak pidana pemilu khususnya subjek peserta haruslah diluruskan dan diselaraskan.

\section{KESIMPULAN}

Pemanfaatan media sosial Instagram dalam kampanye politik sering disalahgunakan oleh banyak oknum yang tidak bertanggung jawab dengan cara menyisipkan muatan black campaign demi tercapainya tujuan politik yang dikehendaki. Efek yang ditimbulkan dengan adanya black campaign lebih dari sekedar pembunuhan karakter sebab jatuhnya nama baik peserta pemilu, tetapi juga berefek bagi masyarakat dalam hal hak untuk mendapatkan suatu informasi berkualitas secara akurat dan objektif, mengingat media sosial Instagram pada masa ini difungsikan sebagai sumber utama informasi. Hal tersebut tidak bisa dianggap remeh, sehingga pelaksanaan kampanye salah satunya kampanye melalui media sosial di Indonesia diatur dalam Undang-Undang Nomor 7 Tahun 2017 Tentang Pemilihan Umum (UU 7/2017) dan diatur pula secara lebih rinci dalam Peraturan Komisi Pemilihan Umum Nomor 28 Tahun 2018 tentang Perubahan atas Peraturan Komisi Pemilihan Umum Nomor 23 Tahun 2018

53 Puteri Hikmawati, Penafsiran terhadap Subjek Pelanggaran Kampanye dalam UU No. 7 Tahun 2017 dan Ancaman Sanksi Pidananya, 7. tentang Kampanye Pemilihan Umum (PKPU 28/2018) yang bertujuan untuk mengurangi sekaligus mencegah maraknya praktek black campaign. Pengaturannya antara lain yakni, membatasi kepemilikan akun media sosial yang akan digunakan dalam berkampanye maksimal 10 (sepuluh) akun untuk setiap jenis platform media sosial. Tidak hanya itu, akun media sosial yang dimaksud harus secara resmi didaftarkan oleh pelaksana kampanye kepada Komisi Pemilihan Umum dan Komisi Independen Pemilihan terkait.

Black Campaign yang dilakukan melalui media sosial Instagram dapat dijerat dengan UU 7/2017 dan UndangUndang Nomor 19 Tahun 2016 Tentang Perubahan Atas Undang-Undang Nomor 11 Tahun 2008 Tentang Informasi Dan Transaksi Elektronik (UU 19/2016). Mengingat black campaign melalui media sosial Instagram termasuk dalam tindak pidana pemilu disamping pula merupakan tindak pidana siber karena erat kaitannya dengan pemanfaatan teknologi. Dapat diberlakukannya UU 7/2017 dan UU 19/2016 ini memunculkan adanya dualisme undang-undang. Selain itu pula, dalam menafsirkan subjek tindak pidana pemilu dalam UU 7/2017 khususnya peserta memang masih beragam, antara peserta kampanye ataukah peserta pemilu yang keduanya tentu mempunyai arti yang berbeda dan keduanya pun berpeluang untuk melakukan tindakan black campaign. Selama ini prakteknya, UU 7/2017 hanya diberlakukan terhadap orang yang mempunyai hubungan langsung dengan pemilu misalnya peserta pemilu dalam hal apabila melakukan black campaign melalui media sosial. Sedangkan anggota masyarakat secara umum yang tidak langsung berhubungan dengan kepentingan pemilu dalam hal ini peserta kampanye, apabila dianggap melakukan black campaign melalui media sosial, maka dijerat dengan UU 19/2016. Oleh karena itu, persepsi mengenai subjek tindak pidana pemilu haruslah diluruskan dan diselaraskan agar pemberlakuannya tidak 
menimbulkan ketidakpastian dan ketidakadilan bagi masyarakat.

\section{DAFTAR PUSTAKA}

\section{Buku}

Arief, Barda Nawawi, Tindak Pidana Mayantara: Perkembangan Kajian Cybercrime Di Indonesia, Jakarta: Rajagrafindo Persada, 2006.

Arifin, Anwar, Komunikasi Politik: Filsafat-Paradigma-Teori-TujuanAplikasi-Strategi dan Komunikasi Politik Indonesia, Jakarta: Graha Ilmu, 2011.

Nimmo, Dan, Komunikasi Politik: Komunikator, Pesan Dan Media, Bandung: Rosda, 2009.

Toha, Miftah, Birokrasi Politik Dan Pemilihan Umum Di Indonesia, Jakarta: Kencana, 2014.

Venus, Antar, Manajemen Kampanye; Panduan Teoritis Dan Praktis Dalam Mengefektifkan Kampanye Komunikasi, Bandung: Simbiosa Rekatama Media, 2004.

\section{Jurnal dan Karya Ilmiah Lainnya}

Achmad, Rafli Fadilah, Ancaman Pidana Bagi Intellectuel Dader Black Campaign: Studi Putusan Nomor 17/Pid.Sus/2014/Pn.Bul, Jurnal Hukum \& Pembangunan, Vol. 48, Nomor 4 (Desember 2018) http://dx.doi.org/10.21143/jhp.vol4 8.no4.1799

Alamsyah, Reza Maulana \& Prahastiwi Utari, Pengaruh Kampanye Hitam (Black Campaign) Pada Pemilih Pemula (Studi Eksperimen Pengaruh Kampanye Hitam (Black Campaign) Pada Kampanye Calon Presiden Dan Calon Wakil Presiden Pemilu 2014 Melalui Media Sosialisasi Dan Diskusi Terhadap Pemahaman Pemilihan Umum Dikalangan Pemilih Pemula Di SMS Negeri 1 Purworejo), Jurnal Komunikasi Massa: Jurnal Ilmu Komunikasi
Universitas Sebelas Maret, Vol. 1 (2016).

Arifuddin, Pengaruh Pesan Politik Caleg PKS Melalui Layanan Pesan Singkat (SMS) Terhadap Sikap Dan Perilaku Pemilih Dalam Pemilu Legislatif 2009 Di Kota Makassar, Jurnal Komunikasi Politik, Vol. 14, Nomor 1 (September 2011) http://dx.doi.org/10.31947/kjik.v1i 3.300

Djuyandi, Yusa, Ari Ganjar Herdiansah \& Jafar Fikri Alkadrie, Sosialisasi Dampak Negatif Black Campaign Terhadap Keamanan Pemilihan Kepala Daerah Tahun 2018 Di Provinsi Jawa Barat, Jurnal Pengabdian Kepada Masyarakat. Vol. 2, Nomor 7 (Juli 2018).

Dodu, Alfred B. David, Penerapan Regulasi Politik Kampanye Hitam: Studi Kasus Pada Pilkada Kabupaten Banggai Tahun 2015, Jurnal Wacana Politik, Vol. 2, Nomor 1 (Maret 2017).

Edytya, Nindya Putri \& Galuh Dwi Novanda, Unsur Sara Dalam Kampanye: Sebuah Studi Komparasi Pilkada Sumatera Utara Dan Dki Jakarta, Seminar Nasional Hukum Universitas Negeri Semarang Vol. 4 Nomor 3 (September 2018).

Fauziyah \& Sri Praptianingsih, Pola Penyelesaian Sengketa Pemilihan Kepala Desa Di Kabupaten Bondowoso, Rechtsidee, Vol. 2, Nomor 1 (Juni 2015) http://dx.doi.org/10.21070/jihr.v2i $\underline{1.8}$

Febriyan, Bayhaqi \& Nursiti, Tindak Pidana Kampanye Hitam (Black Campaign) Dalam Penyelenggaraan Pemilihan Kepala Daerah Walikota Banda Aceh Tahun 2017, Jurnal Ilmiah Mahasiswa: Bidang Hukum Pidana, Vol. 1, Nomor 1 (Agustus 2017). 
Fitri, Adelia, Dinamika Dan Tantangan Jelang Pemilu Presiden Tahun 2019, Kemudi: Jurnal Ilmu Pemerintahan, Vol. 3 Nomor 1 (Agustus 2018).

Fitri, Sherly Nelsa, Pro Kontra Gerakan Tagar \#2019gantipresiden Sebagai Sarana Kampanye Dalam Pemilu, Seminar Nasional Hukum Universitas Negeri Semarang, Vol. 4, Nomor 2 (September 2018).

Guchi, Yuni Fadila, Persepsi Mahasiswa Hukum UMA Dalam Menyikapi Berita Hoax Di Instagram, Skripsi Fakultas Ilmu Sosial Ilmu Politik Universitas Medan Arena (2019).

Herpamudji, Dini Hidayanti, Strategi Kampanye Politik PrabowoHattadan Perang Pencitraan Di Media Massa Dalam Pemilu Presiden 2014, Politika: Jurnal Ilmu Politik, Vol. 6, Nomor 1 (Desember 2015) https://doi.org/10.14710/politika.6. 1.2015.13-24

Hikmawati, Puteri, Penafsiran terhadap Subjek Pelanggaran Kampanye dalam UU No. 7 Tahun 2017 dan Ancaman Sanksi Pidananya, Parliamentary Review, Vol. 1, Nomor 1 (Maret 2019).

Januru, La, Analisis Wacana Black Campaign Pada Pilpres Tahun 2014 Di Media Kompas, Jawa Pos Dan Kedaulatan Rakyat, Jurnal Natapraja, Vol. 4 Nomor 2 (Desember 2017) https://doi.org/10.21831/jnp.v4i2.1 $\underline{2625}$

Kholid, Anwar \& Achmad Nurmandi, Media Sosial Dan Partisipasi Politik mahasiswa Selama Masa Pemilihan Presiden 2014, Jurnal Ilmu Pemerintahan \& Kebijakan Publik, Vol. 2 Nomor 1 (Februari 2015)

http://dx.doi.org/10.18196/Jgpp.20 $\underline{15.0025}$

Krisnanto, Indra Wahyu \& Fitriyah, Strategi Pemasaran Politik Pada
Era Digital: Pemanfaatan Instagram Dalam Kampanye Politik Pada Pilgub DKI Jakarta 2017, Journal Of Politic And Government Studies, Vol 8, Nomor 3 (Agustus 2019).

Marpaung, Jerico Mathias \& Tirta Mulya Wira Pradana, Efektifitas Peradilan Khusus Pemilu Menuju Pilpres 2019, Seminar Nasional Hukum Universitas Negeri Semarang, Vol. 4, Nomor 2 (September 2018) https://doi.org/10.15294/snh.v4i02. 25599

Prasetyoningsih, Nanik, Dampak Pemilihan Umum Serentak Bagi Pembangunan Demokrasi Indonesia, Jurnal Media Hukum, Vol. 21, Nomor 2 (Desember 2014).

Rizaldi, Muhammad, Pro Dan Kontra Black Campaign Dalam Pemilihan Umum Di Indonesia, Fiat Justitia, Vol. 2 Nomor 2 (Oktober 2014).

Setiawan, Andre, Analisis Yuridis Terhadap Berita Bohong (Hoax) Yang Beredar Di Media Sosial Berdasarkan Hukum Positif, Dinamika Hukum: Jurnal Ilmiah Ilmu Hukum, Vol. 25, Nomor 6 (Agustus 2019).

Sumartono, Konstruksi Makna Media Sosial Bagi Anggota DPRD Kota Padang, Al-'Adalah, Vol. 20, Nomor 1 (Mei 2017).

Turistiati, Ade Tuti, Fenomena Black Campaign Dalam Pemilihan Kepala Daerah 2015, Transparansi: Jurnal Ilmiah Ilmu Administrasi, Vol. VIII, Nomor 2 (September 2016) https://doi.org/10.31334/trans.v8i2. $\underline{72}$

Widyawati, Nina, Etnisitas Dan Agama Sebagai Isu Politik, Jurnal Masyarakat Dan Budaya, Vol.17 Nomor 2 (Agustus 2015). 


\section{Online}

Akmal, Mula \& Kiswondari, Masih Kampanye di Medsos Bisa Dijerat Pidana, 15 April, 2019 https://nasional.sindonews.com/rea d/1395865/12/masih-kampanye-dimedsos-bisa-dijerat-pidana1555289961 (diakses 29 Januari 2020).

Salabi, Amalia, Perihal Kampanye Negatif dan Kampanye Hitam Apa Bedanya?, 9 Oktober, 2018 https://rumahpemilu.org/perihalkampanye-negatif-dan-kampanyehitam-apa-bedanya/, (diakses_29 Januari 2020).

Savitri, Galuh A., Media Sosial Dan Black Campaign, 12 Juli, 2018, https://binus.ac.id/malang/2018/07/ media-sosial-dan-black-campaign/ (diakses 3 Januari 2020).

Suyatno, Membungkam Kampanye Hitam, $1 \quad$ Maret, 2019 https://mediaindonesia.com/read/d etail/220097-membungkamkampanye-hitam (diakses 5 Januari 2020).

Taher, Andrian Pratama, Bawaslu Jelaskan Soal Kampanye Iklan Di Medsos, 8 Februari, 2007, https://tirto.id/bawaslu-jelaskansoal-kampanye-iklan-di-medsosciDd (diakses 14 Januari 2020).

Taher, Andrian Pratama, Mahfud MD Benarkan 3 Emak-emak Relawan Pepes Tak Langgar UU Pemilu, 27 Februari, 2019, https://tirto.id/mahfud-mdbenarkan-3-emak-emak-relawanpepes-tak-langgar-uu-pemiludhTH (diakses 28 Januari 2020). 